\title{
Short communication: Comparison of 2 methods of assessing calf birth weights in dairy calves
}

\author{
N. M. Long, ${ }^{* 1}$ R. J. Collier, $†$ and J. F. Smith† \\ *Department of Animal and Veterinary Science, Clemson University, Clemson, SC 29634 \\ †Department of Animal Science, University of Arizona, Tucson 85721
}

\begin{abstract}
The collection of calf birth weight on US dairies is not a common practice. Calf birth weight was collected on 3 dairies (2 Holstein herds and 1 Jersey herd) over a 6 -wk period. All calf birth weights were collected less than $2 \mathrm{~h}$ after birth. A total of 872 calves were weighed by a spring scale and their weight was also estimated using a hoof circumference tape, with both weights and sex recorded. The general linear models procedure (PROC GLM; SAS Institute Inc., Cary, NC) was used to estimate least squares means for spring scale birth weight along with sex of the calf and dairy. Calf spring scale versus hoof circumference-estimated birth weight was compared using the regression procedure (PROC REG; SAS Institute Inc.). Calf birth weight was also broken down into increments, and spring scale versus hoof circumference-estimated birth weight was compared by $t$-test. Bull calves had a heavier birth weight compared with heifer calves $[36.7 \pm 0.4 \mathrm{~kg}(\mathrm{n}=450)$ vs. $34.6 \pm 0.4 \mathrm{~kg}(\mathrm{n}=422)$, respectively]. The dairy on which calves were born had a significant effect on calf birth weight [dairy 1: $36.8 \pm 0.4 \mathrm{~kg}(\mathrm{n}=204)$; dairy 2: $39.5 \pm 0.2 \mathrm{~kg}(\mathrm{n}=463)$; dairy $3: 25.9 \pm 0.4$ $\mathrm{kg}(\mathrm{n}=205)]$. When the spring scale calf birth weight was linearly regressed by hoof circumference-estimated birth weight, a significant relationship was observed, with an $\mathrm{R}^{2}$ value of 0.91 . For calves weighing less than $31.3 \mathrm{~kg}$, the hoof circumference tape overestimated calf birth weight compared with the spring scale. However, for calves that weighed between 31.3 and $44.9 \mathrm{~kg}$, no significant difference was observed between spring scale and hoof circumference tape-estimated birth weight. For calves weighing greater than $44.9 \mathrm{~kg}$, the hoof circumference tape underestimated birth weight compared with the spring scale. Collection of calf BW by spring scale or estimated by hoof circumference tape appeared to be comparable for most calves because most calves
\end{abstract}

Received August 10, 2012.

Accepted September 7, 2012.

${ }^{1}$ Corresponding author: nlong2@clemson.edu weighed between 31 and $45 \mathrm{~kg}$, but caution should be used for calves with a light or heavy birth weight.

Key words: dairy calf, birth weight, hoof circumference tape, trait data collection

\section{Short Communication}

Size at birth can be used as an indicator of fetal growth, particularly in late gestation. However, fetal growth reductions in early and mid gestation caused by maternal nutrient restriction may not result in a difference in fetal weight at late gestation or at birth (Long et al., 2009, 2010). Heat stress and hypothermia can also be possible insults to fetal growth. In beef cows, heat stress can result in decreased gestation lengths (Wright et al., 2007), and hypothermic environments have been shown to have effects on calf birth weights (Deutscher et al., 1999). In dairy cows, heat stress during the last trimester has been shown to result in altered maternal hormone concentrations and a reduced calf birth weight when compared with cows not exposed to heat stress (Collier et al., 1982). In a subsequent study, the dry period in dairy cows was reduced by $7 \mathrm{~d}$ by heat stress when all cows were dried off $46 \mathrm{~d}$ before expected parturition, and it also resulted in a 13-kg reduction in calf birth weight (do Amaral et al., 2009).

Calf birth weights are not routinely collected on dairies in the United States. The inclusion of calf birth weight data could allow dairies to make better decisions about calf rearing and even cow management. Swali and Wathes (2006) showed that heifer calves from high-milk-producing dams were more likely to be born with a lighter birth weight compared with heifer calves whose dams produced less than $42 \mathrm{~kg}$ of milk/d and that calf sire affected gestation length but not calf birth weight. In dairy cows, increased calf birth weight is related to an increased incidence of dystocia (Sieber et al., 1989; Linden et al., 2009). In addition, the probability of perinatal mortality (death within 48 $\mathrm{h}$ of birth) was increased from $2.1 \%$ for calves weighing $29 \mathrm{~kg}$ at birth to $9.6 \%$ for calves weighing $52 \mathrm{~kg}$ at birth (Johanson and Berger, 2003). In addition, calves that are born with either a high or a low birth weight 
were more likely to have an incidence of diarrhea at an earlier age compared with calves born at a normal weight (Paré et al., 1993). Increased calf birth weight has been associated with increased odds of lameness in the cow during the following lactation (Linden et al., 2009). Multiple methods are used for collecting calf birth weights. In beef cows, collection of calf birth weight by hoof circumference tape tended to underestimate high-birth-weight calves and tended to overestimate low-birth-weight calves compared with weighing by spring or digital scale (Parish et al., 2009). However, no studies have evaluated methods of calf birth weight collection in dairy calves. Our hypothesis is that the hoof circumference tape will accurately measure calf birth weight on most calves and, considering the ease of use, could result in increased collection of dairy calf birth weights.

Calf birth weight was collected at 3 commercial dairies in the greater Phoenix, Arizona, area over a 6-wk period beginning at the end of November 2011 and ending the first week of January 2012. Dairies 1 and 2 were milking Holsteins and dairy 3 was milking Jerseys. Within $2 \mathrm{~h}$ of parturition, calf birth weight was collected using a spring scale (Rubbermaid Co., Huntersville, NC) and estimated using a hoof circumference tape (Calfscale BW Tape; Nasco, Fort Atkinson, WI). Birth weight and calf sex were recorded by dairy employees for all calves born on each dairy. All calves were weighed before colostrum was given. Before the start of the study, all employees were trained in the correct ways to collect calf birth weights using both methods. For collection of calf birth weights by spring scale, the scale was hung by a rope, the calf was placed in a calf weighing sling (Munks Livestock, Anacortes, WA), and the sling was placed on the hook of the scale. The scale weight reading was allowed to stabilize before the weight of the calf was recorded. For calf birth weight estimation by hoof circumference tape, the anterior left hoof of the calf was used, and the tape was placed around the coronary band to take the measurement. The technician ensured that the correct side of the tape was being used for bull and heifer calves according to the manufacturer's instructions.

The general linear models procedure of SAS (PROC GLM; SAS Institute Inc., Cary, NC) was used to estimate least squares means for the response variables of spring scale birth weight, sex of calf, and dairy. All interactions were initially included in the model statement but were removed when found to be nonsignificant $(P>0.26)$. Linear and quadratic regressions, with spring scale birth weight as the dependent variable and hoof circumference tape-estimated birth weight as the independent variable, were conducted using the regression procedure of SAS (PROC REG; SAS Institute
Inc.). Calf spring scale birth weight was also broken down into increments $(<27.2,27.2-31.3,31.3-35.8$, $35.8-40.4,40.4-44.9$, and $>44.9 \mathrm{~kg})$, and PROC GLM of SAS was then used to calculate least squares means and standard errors of the mean for both spring scale and hoof circumference tape birth weight for each increment. The $t$-test $P$-values were also calculated by comparing the 2 birth weight measurements.

On dairy 1, 263 bull and 200 heifer calves were born during the collection period, with a range in birth weights of $18.1-63.0$ and $27.2-49.0 \mathrm{~kg}$, respectively. On dairy 2, 88 bull and 115 heifer calves were born, with a range of birth weights of $28.1-49.3$ and $22.2-46.3 \mathrm{~kg}$, respectively. On dairy 3, 99 bull and 106 heifer calves were born during this period of data collection, with ranges in birth weights of $15.4-51.7$ and $15.9-55.3 \mathrm{~kg}$, respectively. The dairy on which calves were born had a significant effect $(P<0.001)$ on calf birth weight [dairy $1: 36.8 \pm 0.4 \mathrm{~kg}(\mathrm{n}=204)$; dairy $2: 39.5 \pm 0.2 \mathrm{~kg}$ (n $=463)$; dairy 3: $25.9 \pm 0.4 \mathrm{~kg}(\mathrm{n}=205)]$. Overall, bull calves had heavier $(P<0.001)$ birth weights compared with heifer calves $[36.7 \pm 0.4 \mathrm{~kg}(\mathrm{n}=450)$ vs. $34.6 \pm$ $0.4 \mathrm{~kg}(\mathrm{n}=422)$, respectively].

When the spring scale calf birth weight was linearly regressed by hoof circumference tape-estimated birth weight, a significant relationship $(P<0.01)$ was observed, with a $R^{2}$ value of 0.91 (Figure 1a). When the model was changed to a quadratic model, a significant relationship $(P<0.01)$ was also observed, and the $\mathrm{R}^{2}$ value increased to 0.93 (Figure 1a). The breakdown of calf birth weights and a comparison of spring scale and hoof circumference tape-estimated birth weights are shown in Table 1. For calves weighing less than 31.3 $\mathrm{kg}$, the hoof circumference tape overestimated $(P<$ 0.001) calf birth weight compared with the spring scale. However, for calves that weighed between 31.3 and 44.9 $\mathrm{kg}$, no difference was observed between the spring scale and hoof circumference tape-estimated birth weight $(P$ $\geq 0.10$ ). For calves weighing more than $44.9 \mathrm{~kg}$, the hoof circumference tape underestimated $(P=0.02)$ birth weight compared with the spring scale.

Collection of calf birth weight by spring scale or hoof circumference tape appeared to be comparable for the majority of calves because most calves weighed between 31 and $45 \mathrm{~kg}$ at birth; however, caution should be used for calves with a light or heavy birth weight. The use of spring scales often requires lifting the calf and reading the scale at the same time and can lead to inaccurate measures. However, the ease of collecting calf birth weights by hoof circumference tape could make collecting birth weight a type of data commonly collected on US dairies. Even with the slight overestimation and underestimation for calves with a light and heavy birth weight, respectively, the data could be of great help to 
Table 1. Comparison of spring scale and hoof circumference tape for birth weight determination on production dairies

\begin{tabular}{|c|c|c|c|c|c|c|}
\hline \multirow[b]{2}{*}{ Weight $(\mathrm{kg})$} & \multirow[b]{2}{*}{$\mathrm{n}$} & \multicolumn{2}{|c|}{ Spring scale } & \multicolumn{2}{|c|}{$\begin{array}{c}\text { Hoof } \\
\text { circumference tape }\end{array}$} & \multirow[b]{2}{*}{$t$-test $P$-value } \\
\hline & & Mean & SEM & Mean & SEM & \\
\hline$<27.2$ & 148 & 23.2 & 0.2 & 24.6 & 0.3 & $<0.001$ \\
\hline $27.2-31.2$ & 95 & 28.9 & 0.2 & 29.7 & 0.2 & $<0.001$ \\
\hline $31.3-35.7$ & 135 & 33.8 & 0.1 & 34.0 & 0.1 & 0.22 \\
\hline $35.8-40.3$ & 242 & 38.0 & 0.1 & 37.8 & 0.1 & 0.13 \\
\hline $40.4-44.9$ & 165 & 42.4 & 0.1 & 42.2 & 0.2 & 0.10 \\
\hline$>44.9$ & 87 & 47.4 & 0.3 & 46.5 & 0.4 & 0.02 \\
\hline
\end{tabular}

the US dairy industry. The collection of birth weights could allow for the calculation of birth weight and calving ease expected progeny difference similar to what is currently in place in beef breeds. This would allow dairy personnel to begin selecting for less dystocia and its negative effects on calf survivability and cow performance (Sieber et al., 1989; Johanson and Berger, 2003; Linden et al., 2009).

It should not be surprising that calf birth weights were different between dairies in this study; one dairy
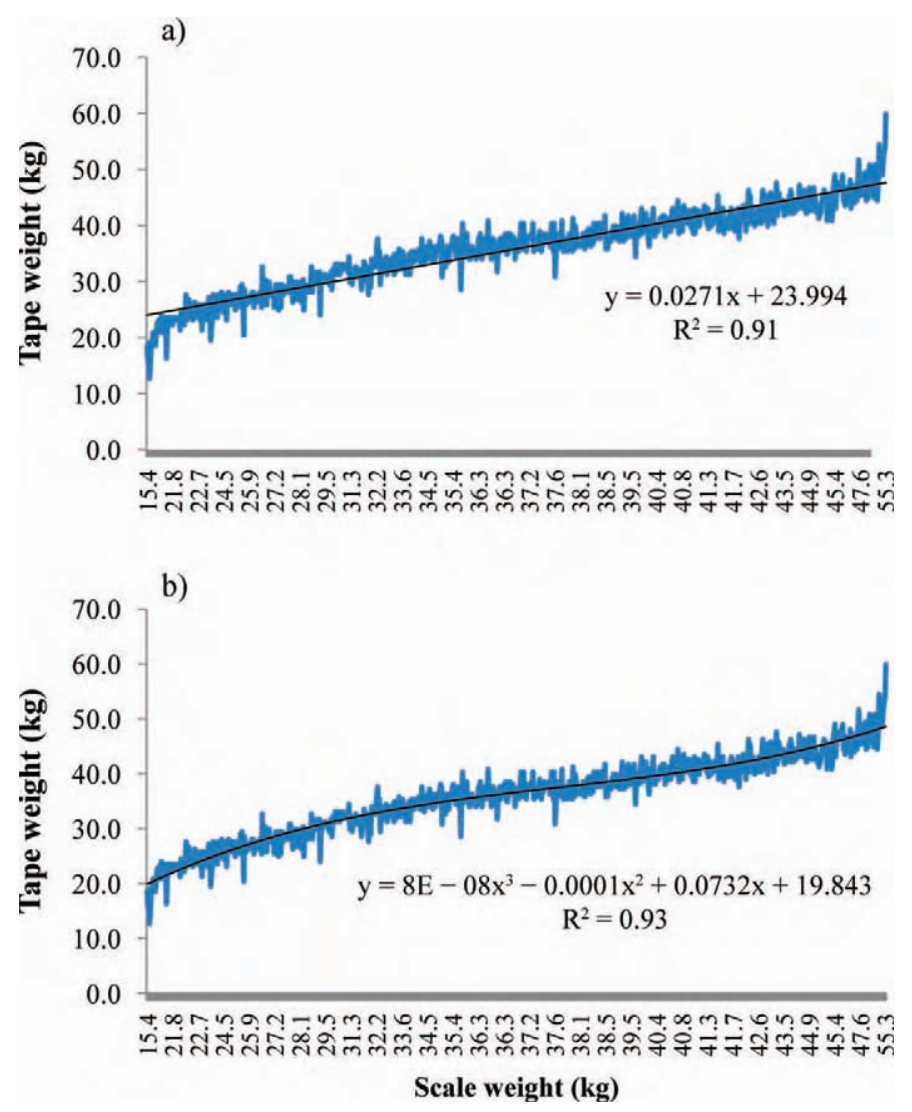

Figure 1. Linear (a) and quadratic (b) regression analysis of hoof circumference tape versus spring scale for calf birth weight determination. Color version available in the online PDF. was milking a Jersey herd and the other 2 dairies were milking Holsteins. Even in the 2 dairies milking Holsteins, the genetics did not appear similar enough to result in similar calf birth weights. Bull calves were $2.1 \mathrm{~kg}$ heavier than heifers in this group of calves. This result is in agreement with some older literature (Vail et al., 1965) and also more current beef cattle results (Parish et al., 2009).

The collection of calf birth weights on commercial dairies could lead to the collection of data that would allow us to better understand the effect of environment on calf birth weight, which can be an indicator of fetal development and also of future calf performance. The supply of nutrients available to the developing bovine fetus is influenced by maternal age and BCS (Long et al., 2009, 2010). In sheep, the size of the placenta also has been shown to affect fetal growth and become rate limiting in late gestation, resulting in decreased weight of the newborn at birth (Kelly, 1992; Ehrhardt and Bell, 1995; McMillen et al., 2001). Cattle subjected to chronic environmental heat stress during the last twothirds of pregnancy exhibit reduced uterine and umbilical blood flows in association with reduced fetal oxygen and nutrient uptakes as well as decreased fetal size (Reynolds et al., 1985). The use of hoof circumference tape to determine calf birth weight could allow for more data collection on US dairies and thereby give dairy producers a better understanding of environmental, genetic, and physiological factors that affect their herds.

\section{ACKNOWLEDGMENTS}

The authors thank the Arizona Dairy Company (Mesa, AZ), Caballero Dairy Farms (Gilbert, AZ), and Rovey Dairy (Glendale, AZ) for their assistance with this research trial.

\section{REFERENCES}

Collier, R. J., S. G. Doelger, H. H. Head, W. W. Thatcher, and C. J. Wilcox. 1982. Effects of heat stress during pregnancy on maternal 
hormone concentrations, calf birth weight and postpartum milk yield of Holstein cows. J. Anim. Sci. 54:309-319.

Deutscher, G., D. Colburn, and R. Davis. 1999. Climate affects calf birth weights and calving difficulty. Accessed Mar. 19, 2012. http://digitalcommons.unl.edu/cgi/viewcontent.cgi?article $=1400$ \&context=animalscinbcr.

do Amaral, B. C., E. E. Conner, S. Tao, J. Hayen, J. Bobolz, and G. E. Dahl. 2009. Heat-stress abatement during the dry period: Does cooling improve transition into lactation. J. Dairy Sci. 92:59885999.

Ehrhardt, R. A., and A. W. Bell. 1995. Growth and metabolism of the ovine placenta during mid-gestation. Placenta 16:727-741.

Johanson, J. M., and P. J. Berger. 2003. Birth weight as a predictor of calving ease and perinatal mortality in Holstein cattle. J. Dairy Sci. 86:3745-3755.

Kelly, R. W. 1992. Nutrition and placenta development. Proc. Nutr. Soc. Aust. 17:203-211.

Linden, T. C., R. C. Bicalho, and D. V. Nydam. 2009. Calf birth weight and its association with calf and cow survivability, disease incidence, reproductive performance and milk production. J. Dairy Sci. 92:2580-2588.

Long, N. M., M. J. Prado-Cooper, C. R. Krehbiel, U. DeSilva, and R. P. Wettemann. 2010. Effects of nutrient restriction of bovine dams during early gestation on postnatal growth, carcass and organ compositions, and gene expression in adipose tissue and muscle. J. Anim. Sci. 88:3251-3261.

Long, N. M., K. A. Vonnahme, B. W. Hess, P. W. Nathanielsz, and S. P. Ford. 2009. Effects of early gestational undernutrition on fetal growth, organ development, and placentomal composition in the bovine. J. Anim. Sci. 87:1950-1959.
McMillen, I. C., M. B. Adams, J. T. Ross, C. L. Coulter, G. Simonetta, J. A. Owens, J. S. Robinson, and L. J. Edwards. 2001. Fetal growth restriction: Adaptations and consequences. Reproduction 122:195-204

Paré, J., M. C. Thurmond, I. A. Gardner, and J. P. Picanso. 1993. Effect of birthweight, total protein, serum IgG and packed cell volume on risk of neonatal diarrhea in calves on two California dairies. Can. J. Vet. Res. 57:241-246.

Parish, J. A., T. Smith, J. R. Parish, T. F. Best, and H. T. Boland. 2009. Evaluation of four different methods of calf birth weight data collection. Prof. Anim. Sci. 25:716-721.

Reynolds, L. P., C. L. Ferrell, J. A. Nienaber, and S. P. Ford. 1985. Effects of chronic environmental heat-stress on blood flow and nutrient uptake of the gravid bovine uterus and foetus. J. Agric. Sci. 104:289-297.

Sieber, M., A. E. Freeman, and D. H. Kelly. 1989. Effects of body measurements and weight on calf size and calving difficulties of Holsteins. J. Dairy Sci. 72:2402-2410.

Swali, A., and D. C. Wathes. 2006. Influence of the dam and sire on size at birth and subsequent growth, milk production and fertility in dairy heifers. Theriogenology 66:1173-1184.

Vail, V. E., G. J. More, and O. Ferrall. 1965. The effects of breed, sex, season, and age of dam on birthweight of dairy and crossbred calves and their growth during the first seven days of age. Isr. J. Agric. Res. 4:223-230.

Wright, E. C., M. J. Prado-Cooper, N. M. Long, and R. P. Wettemann. 2007. Effects of elevated ambient temperature on gestation lengths of beef cows. Accessed Mar. 16, 2012. http://www.ansi. okstate.edu/research/research-reports-1/2007/2007-researchreports. 